\title{
Editor's Note: An Introduction
}

\author{
Martin Covey
}

In 2006 I assumed the editorship of Michigan Family Review from Libby Blume. I would like to take a moment to thank Dr. Blume for her support during my editorship of MFR. Libby has been a tremendous source of support and insight as I learned the ropes of being an editor of a peer reviewed journal. She was always available, providing assistance, advice, and expertise when called upon.

It was through Libby's contacts and subsequent work that Michigan Family Review became an on-line, electronic journal, free of charge to all readers through the Scholarly Publishing Office of the University of Michigan Library. With the considerable expertise and technology now available through the Scholarly Publishing Office, Michigan Family Review can not only be accessible to all readers at no cost, but future editions can explore publishing and academic writing with new options using new ways of communicating information for and about families. Thank you, Libby, for your insight and knowing a good deal when you see it.

Now I would like to introduce the new editor of Michigan Family Review - Dr. Bradley van Eeden-Moorefield. Dr. van Eeden-Moorefield is a faculty member in the Graduate Department of Human Development and Family Studies at Central Michigan University. His Ph.D. is in Human Development and Family Studies, which places him firmly in the center academic dialogue regarding family studies and family life education in Michigan. Furthermore, he has a Master's of Social Work degree along with experience in the field that gives him a view to the concerns and issues for practitioners involved in assisting families.

Dr. van Eeden-Moorefield's teaching interests include couple relationship formation and maintenance over the life course, relationship education, family diversity, family theory, research methods, and statistics. His research interests include the development and testing of theoretical models that help explain the development of romantic relationships, especially issues surrounding relationship quality and couple identity, and the role of social networks and social support in producing such outcomes. He also has an interest in the use of the internet as a research instrument used to gather both quantitative and qualitative data.

Additionally, Dr. van Eeden-Moorefield comes to MFR with a solid editorial experience, most notably with Family Relations Journal of 
NCFR. In my discussions with Brad it became evident that he has the heart of a writer combined with the head and eyes of an editor. Dr. van Eeden-Moorefield's natural inclinations, coupled with his experience give me every reason to be excited for the future of the Michigan Family Review.

Brad's first issue is "Innovations in Teaching \& mentoring Family Scholars \& Practitioners." We invite you to submit articles or book reviews to him at vanee1bm@cmich.edu.

\author{
Martin Covey \\ Spring Arbor University \\ Spring Arbor, Michigan
}

